\title{
減肉管の外圧による圧壊変形に関する研究*
}

\author{
柴田俊忍 ${ }^{* *}$ 中 井宏***藤 浪 清***
}

\section{A Study on Failure of Partially Thinned Pipes by External Pressure}

by

\author{
Toshinobu Shibata, Hiroshi NakaI and Kiyoshi Fujinami \\ (Faculty of Engineering, Kyoto University, Kyoto)
}

\begin{abstract}
It is important to prevent the buckling of thin pipes caused by an external pressure in the heat-exchanger system of a pressurized water reactor. The design code in ASME Sec. III NB considers this point. However, the thickness of pipes is partially thinned down by steam-liquid flow in service, and in design step no consideration is being paid to such a partially thinned down pipe, though much attention should be paid on this point.

In this paper, the pressure at failure of a partially thinned pipe under an external pressure was studied. The experimental results show that the failure occurs at unexpectedly small pressure, if the thinned part has some expansion in area, and that the pressure at failure does not follow with the buckling equation given by elastic theory for thin cylinders.
\end{abstract}

キー・ワード : 減肉管の座屈, 蒸気発生細管, 原子力発電所

(Received Dec. 9, 1978)

\section{1 は じめに}

通常用いられる配管系に执いては, 内圧による強度 が大きな問題となり，特殊な使用状態を除いて外圧に よる圧壊, 座属を考慮する必要はない, しかし加圧水 型原子炉の一次と二次冷却水の熱交換用細管のように， 内圧 $\left(150 \mathrm{~kg} / \mathrm{cm}^{2}\right)$ と外圧 $\left(75 \mathrm{~kg} / \mathrm{cm}^{2}\right)$ が同時に加 わっているような場合には, 故障や事故を想定して, 外扯による圧壊を予的考慮して和く事が要求される.

特に上記の熱交換器の蒸気細管においては, 管の外 周部が部分的に減肉されていることが報告されている. このような減肉部をもつ細管が外圧に対してどれほど の強度を有しているかについては報告がない，本研究 に拈いては, 蒸気細管と同一寸法の呼び径20の管に減 肉部を作り，外圧を加兄て圧壊試験を行い，その結果 について考察を行った.

\section{2 実 験 方 法}

\section{$2 \cdot 1$ 供試材料}

実験に用いた 円管は JIS G 3425 の高圧配管用管 (SGP ; P : 0.05\%以下, $S: 0.05 \%$ 以下, $\mathrm{C}: 0.2 \%$ 以下）で，呼び径20である，管は入手状態のまま熱処

\footnotetext{
* 本報を「パイプ破断に関する研究 (第 1 報)」(Study on Pipe Rupture, I) とする. 原稿受理 昭和53年12月 9 日

** 正 会 員 京都大学工学部 京都市左京区吉田本町

*** 京都大学工学部 京都市左京区吉田本町
}

理を行わずに加工し，実験に供したが，一部比較のた め試験片加工後真空焼なむしを施した。そ务件は, $700^{\circ} \mathrm{C}$ で30分のものと, $900^{\circ} \mathrm{C} て ゙ 60$ 分の 2 種類である. JIS Z2201 の11号試験片による引張試験の結果（それ ぞれ 3 本ずつの平均) を Table I に示した.

Table I. Mechanical properties of the specimen.

\begin{tabular}{l|c|c|c|c}
\hline $\begin{array}{l}\text { Heat } \\
\text { treatment }\end{array}$ & $\begin{array}{c}\text { Upper yield } \\
\text { point } \\
\left(\mathrm{kg} / \mathrm{mm}^{2}\right)\end{array}$ & $\begin{array}{l}\text { Lower yield } \\
\text { point } \\
\left(\mathrm{kg} / \mathrm{mm}^{2}\right)\end{array}$ & $\begin{array}{c}\text { Tensile } \\
\text { strength } \\
\left(\mathrm{kg} / \mathrm{mm}^{2}\right)\end{array}$ & $\begin{array}{c}\text { Elongation } \\
(\%)\end{array}$ \\
\hline As rolled & 258 & - & 371 & 405 \\
$\begin{array}{c}700^{\circ} \mathrm{C} 30 \mathrm{~min} . \\
\text { Annealing }\end{array}$ & 23.0 & 21.3 & 33.0 & 516 \\
$\begin{array}{c}\text { 900'C 60 min. } \\
\text { Annealing }\end{array}$ & 20.1 & 19.4 & 31.3 & 500 \\
\hline
\end{tabular}

* JIS Z 2201 Type 11 was tested.

* Values show the mean of three specimens respectively.

\section{$2 \cdot 2$ 試験片}

供試管を内径 $22 \mathrm{~mm}$, 外径 $26 \mathrm{~mm}$ 飞旋削した後, Fig. 1 亿示す形に減肉部分をフライス加工した。減肉 部分は図示のように, 減肉角 $\theta$, 減肉長さ $l$, 特よび 減肉部の肉厚 $t$ を実験のパラメータとなるようにして いる. 減肉部の加工は, 供試管の内側に芯材を入れて 割出し台に固定し，エンドミル（径 $10 \mathrm{~mm}$ ) の側面 を用いて管の軸方向に $l$ の長さだけ減肉し，次いで割 出し台を用いて $5^{\circ}$ なは $10^{\circ}$ 回転させて同柡の減肉 


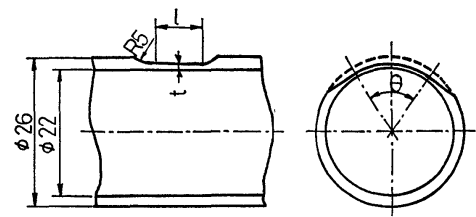

Fig. 1. Test specimen.

加工を行らといら方法を用いた．割り出し台を用いて $10^{\circ}$ ずつ回転させるときと生ずる減肉部厚さの誤差は

$$
\Delta t=(2-t) / \cos \frac{10^{\circ}}{2}-2(\mathrm{~mm})
$$

であり, $t=0.1 \mathrm{~mm}$ のとき, $\Delta t=0.042 \mathrm{~mm}$ である. 割り出し角 $5^{\circ}$ で $\Delta t=0.1 \mathrm{~mm}$ のとき $\Delta t=0.011 \mathrm{~mm}$ の大きさである.

試験片の両端には厚さ $3 \mathrm{~mm}$ のアルミニウム板をア ラルダイト接着剤で接着し密封した。加圧試験中, ア ルミニウム板の凹反変形は高圧力域で 2,3 生じたが, 接着部分の破損や, 洩饥は生じなかった。

\section{$2 \cdot 3$ 加圧装置}

本研究のために, 耐圧強度 $200 \mathrm{~kg} / \mathrm{cm}^{2}$, 内容積 $6 \mathrm{l}$ の圧力容器を作った. この容器中に試験片を入れ, 手 動ポンプにより加圧した. 圧力は共和電業製圧力変換 器 PG-200KU (容量 $200 \mathrm{~kg} / \mathrm{cm}^{2}$ ) を用いて検出し, ひずみ計を介してペン書きオッシロあるいは $\mathrm{X}-\mathrm{Y}$ 記 録計に記録した.

な扔圧壊するときの圧力は，圧壊が座屈現象の一つ であることから，不安定変形時に生ずる可聴音によっ て, あるいは圧壊時に生ずる試験片の内容積の変化に 伴って記録紙上に現れてくる圧力低下ょり読み取った。 試験片の一部には減肉部分に電気抵抗線ひずみゲージ を貼付し，圧力ーひずみ曲線として X-Y 記録計と記録 し，考察の助けとした.

\section{3 実 験 結 果}

熱処理をしない状態で, かつ割り出し角 $10^{\circ}$ で加工 した試験片による結果を, 減肉部の寸法および後述の (6)式より計算される圧壊圧力とあわせて Table II に 示した. $l=0 \mathrm{~mm}$ に対しては, $t=0.1 \mathrm{~mm}, \theta=90^{\circ}$ でも, 外圧 $200 \mathrm{~kg} / \mathrm{cm}^{2}$ で圧壊も変形も生じないが, $l=20 \mathrm{~mm}, \theta=70^{\circ}, t=0.12 \mathrm{~mm}$ では外圧 $15 \mathrm{~kg} / \mathrm{cm}^{2}$ で圧壊している. Fig. 2 は圧壊状沉を例示したもので ある. 寸法扔よび圧壊圧力は図示のと抒りである. 図 示のごとく，外圧を加觉ると，試験片には変形が生じ， 次いで破断（開口）する. Fig. 2 (a)の場合, 外圧 130 $\mathrm{kg} / \mathrm{cm}^{2}$ に括いて図示のような変形と減肉部の肩部の 所飞小孔が生じ, 油が管内に侵入している. Fig. 2 (b) の場合には, 外圧 $33 \mathrm{~kg} / \mathrm{cm}^{2}$ で変形が生じ, $33 \sim 45$ $\mathrm{kg} / \mathrm{cm}^{2}$ の圧力間に開口しているが，開口時の圧力を 特定することは困難であった。このように，一般に開
Table II. Comparison of experimental results with calculated values.

\begin{tabular}{|c|c|c|c|c|}
\hline \multicolumn{3}{|c|}{ Dimension of thinned part } & \multicolumn{2}{|c|}{$\begin{array}{l}\text { Failured pressure } \\
\qquad\left(\mathrm{kg} / \mathrm{cm}^{2}\right)\end{array}$} \\
\hline $\begin{array}{l}\text { Length } \\
l(\mathrm{~mm})\end{array}$ & $\begin{array}{c}\text { Angle } \\
\theta \text { (deg.) }\end{array}$ & $\begin{array}{l}\text { Thickness } \\
t(\mathrm{~mm})\end{array}$ & $\begin{array}{c}\text { Exptl. } \\
P_{e} \\
\end{array}$ & $\begin{array}{c}\text { Calcultd. } \\
P_{c}\end{array}$ \\
\hline \multirow{6}{*}{30} & 90 & $\begin{array}{ll}0 & 60 \\
0 & 35\end{array}$ & $\begin{array}{r}184 \\
66\end{array}$ & $\begin{array}{r}184.0 \\
75.7\end{array}$ \\
\hline & 70 & $\begin{array}{l}057 \\
0.41 \\
0226 \\
0.26\end{array}$ & $\begin{array}{r}178 \\
110 \\
62 \\
52\end{array}$ & $\begin{array}{r}170.1 \\
98.8 \\
47.9 \\
47.9\end{array}$ \\
\hline & 50 & $\begin{array}{ll}0 & 49 \\
0.41 \\
0 & 33 \\
0.19\end{array}$ & $\begin{array}{r}149 \\
116 \\
74 \\
22\end{array}$ & $\begin{array}{r}134.2 \\
100.5 \\
71.1 \\
30.8\end{array}$ \\
\hline & 30 & $\begin{array}{ll}0.48 \\
0 & 42 \\
0 & 30 \\
0.21\end{array}$ & $\begin{array}{r}149 \\
135 \\
86 \\
43\end{array}$ & $\begin{array}{r}133.7 \\
108.1 \\
64.2 \\
38.0\end{array}$ \\
\hline & 10 & $\begin{array}{ll}0.54 \\
0 & 38 \\
0 & 28 \\
0 & 20\end{array}$ & $\begin{array}{r}163 \\
122 \\
80 \\
40\end{array}$ & $\begin{array}{r}177.5 \\
1047 \\
680 \\
43.8\end{array}$ \\
\hline & 0 & $\begin{array}{ll}0 & 31 \\
0 & 22 \\
0 . & 11 *\end{array}$ & $\begin{array}{l}82 \\
55 \\
54\end{array}$ & $\begin{array}{rl}116 & 3 \\
80 & 1 \\
34 & 9\end{array}$ \\
\hline \multirow{6}{*}{20} & 90 & $\begin{array}{ll}0 & 65 \\
0 & 55 \\
0 & 48 \\
0.38 \\
0 & 35\end{array}$ & $\begin{array}{r}>200 \\
168 \\
150 \\
107 \\
90\end{array}$ & $\begin{array}{r}224.1 \\
171.0 \\
137.7 \\
95.6 \\
84.2\end{array}$ \\
\hline & 70 & $\begin{array}{l}075 \\
0.55 \\
0.45 \\
012\end{array}$ & $\begin{array}{r}>200 \\
167 \\
141 \\
15\end{array}$ & $\begin{array}{r}2848 \\
172.3 \\
125.4 \\
197\end{array}$ \\
\hline & 50 & $\begin{array}{ll}0 & 65 \\
0 & 51 \\
0.41 \\
0 & 30 \\
0.19\end{array}$ & $\begin{array}{r}>200 \\
156 \\
122 \\
84 \\
36\end{array}$ & $\begin{array}{r}227.9 \\
1549 \\
110.4 \\
692 \\
36.6\end{array}$ \\
\hline & 30 & $\begin{array}{l}0.50 \\
0.37 \\
030 \\
020 \\
0.10\end{array}$ & $\begin{array}{r}154 \\
122 \\
77 \\
67 \\
30\end{array}$ & $\begin{array}{r}154.5 \\
98,1 \\
725 \\
41.9 \\
18.9\end{array}$ \\
\hline & 10 & $\begin{array}{ll}0 & 52 * \\
0 & 30 \\
0.14 \\
0.14\end{array}$ & $\begin{array}{r}130 \\
79 \\
25 \\
41\end{array}$ & $\begin{array}{r}180.7 \\
84.4 \\
35.6 \\
35.6\end{array}$ \\
\hline & 0 & $\begin{array}{l}039 \\
030 \\
0.22\end{array}$ & $\begin{array}{l}175 \\
172 \\
108\end{array}$ & $\begin{array}{r}168.6 \\
126.4 \\
93.5\end{array}$ \\
\hline \multirow{5}{*}{10} & 70 & $\begin{array}{ll}0 & 50 * \\
0 . & 50 * \\
0 . & 30 \\
0 & 17\end{array}$ & $\begin{array}{r}155 \\
168 \\
96 \\
33\end{array}$ & $\begin{array}{r}186.5 \\
186.5 \\
94.1 \\
48.4\end{array}$ \\
\hline & 50 & $\begin{array}{l}050 * \\
0.31 \\
0.15\end{array}$ & $\begin{array}{r}110 \\
97 \\
37\end{array}$ & $\begin{array}{r}1891 \\
100.3 \\
44.1\end{array}$ \\
\hline & 30 & $\begin{array}{l}037 \\
0.29 \\
0220\end{array}$ & $\begin{array}{r}142 \\
101 \\
54\end{array}$ & $\begin{array}{r}1307 \\
96.8 \\
639\end{array}$ \\
\hline & 10 & $\begin{array}{ll}0 & 50 \\
0 & 27 \\
0.15 *\end{array}$ & $\begin{array}{r}200 \\
65 \\
55\end{array}$ & $\begin{array}{r}215.0 \\
1052 \\
62.1\end{array}$ \\
\hline & 0 & 0.20 & $>200$ & 131.0 \\
\hline \multirow{5}{*}{0} & 90 & $\begin{array}{ll}0 & 40 \\
0 & 15\end{array}$ & \multirow{5}{*}{$>200$} & \multirow{5}{*}{$>200$} \\
\hline & 50 & 010 & & \\
\hline & 20 & $\begin{array}{l}015 \\
0.05\end{array}$ & & \\
\hline & 10 & $\begin{array}{l}020 \\
0.10\end{array}$ & & \\
\hline & 0 & 010 & & \\
\hline
\end{tabular}

These specimens are the retested specimens which did not failure at $l=0 \mathrm{~mm}$. 


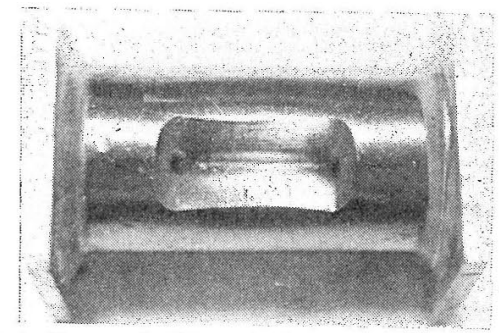

(a) $l=20 \mathrm{~mm}, \theta=10^{\circ}, t=0.52 \mathrm{~mm}, P_{e}=130 \mathrm{~kg} / \mathrm{cm}^{2}$

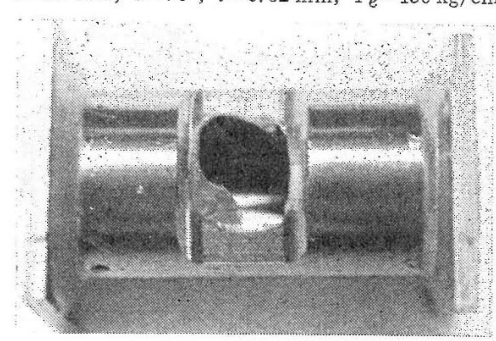

(b) $l=10 \mathrm{~mm}, \theta=70^{\circ}, t=0.17 \mathrm{~mm}, P_{e}=33 \mathrm{~kg} / \mathrm{cm}^{2}$

Fig. 2. Examples of pipe failured by external pressure.

口時の圧力を明確にでさなかったので，座屈による不 安定変形を生したときの非力压壇圧力とした。

Table II に示した死力はこの值である。

な标, Table II 中, *印の付した試験片は $l=0 \mathrm{~mm}$ で $200 \mathrm{~kg} / \mathrm{cm}^{2}$ の压力下で圧壊しなかったるのについ て, その $l=0 \mathrm{~mm}$ の減肉部の裏側に, 表記の減肉部 学加工したものである。

つぎに割り出し角度を $5^{\circ}$ 叔よび $10^{\circ}$ に変化させた ときの影響を示したものが Fig.3である。図中実線 は後述の(6)式より計算した子のである。図より割り出 し角度によって压猿圧力には殆えど差がないので，割 り出乙角度を $10^{\circ}$ とて試験片を加工したことによる 影響はないものとして考察な進めた。

圧壤王力に及添す熱処理の影響定示したのが Fig.4 である。熟処理を施した場合，压懐圧力はかなり減少 するがこれは㾕なるしよって延性が嬶加するためと 考党られる，実際の使用状沉は入手状態に近いと考光

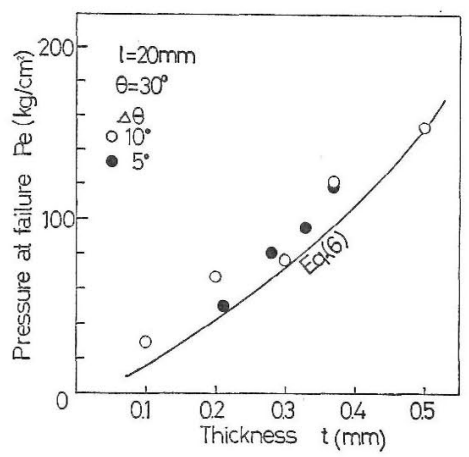

Fig. 3. Effect of machining angle by index-head on result.

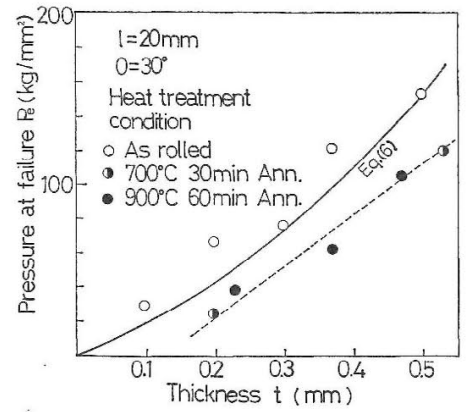

Fig. 4. Effect of heat treatment on result.

られるので以後の考察では熱然理をしない材料の結果 起対象亡する。

\section{4 実験結果の考察}

\section{$4 \cdot 1$ 薄肉円管の座屆の式}

円管の圧壞 (座屈) 圧力 $P_{\mathrm{er}}$ は, 円管断面内で平面 応力的に解いたときに，次式で与亮学る。

$$
P_{\text {cr }}=\frac{E}{4\left(1-\nu^{2}\right)}\left(\frac{t}{r_{0}}\right)^{3}
$$

E:サング率

レ:ポアソン比

$t:$ 薄肉円管の肉厚

$r_{0}:$ 薄肉円管の半径

この式では円管の長さの影響が入れられていない.円 管の長さ $れ$ を加味し，円管の軸方向示よび半径方向か ら加圧されたときの座屈圧力はVon Mises によって 次式のように与えられている。

$$
\begin{aligned}
P_{c r}= & \frac{E t}{r_{0}} \times \frac{1}{n^{2}+\left(\pi r_{0} / l\right)^{2} / 2} \times\left\{\frac{1}{\left[n^{2}\left(l / \pi r_{0}\right)^{2}+1\right]^{2}}\right. \\
& \left.+\frac{t^{2}\left[n^{2}+\left(\pi r_{0} / l\right)^{2}\right]^{2}}{12 r_{0}^{2}\left(1-\nu^{2}\right)}\right\}
\end{aligned}
$$

式中 $n$ は座屈の次数で苛る。 $l \rightarrow \infty$ となったとき, $P_{c r}$ の值は $\left(t / r_{0}\right)^{3}$ の值に比例するが，軸方向の圧力至考 えているから(1)式とは一致しないのは当然である。

Fig. 3 拈よび 4 より明らかなように，圧壊圧力は $t^{3}$ には比例せず， $t$ の指数は 3 よりむ小さく，ほば 1.5 で活ることが予想できる。(1)，(2)式とも，今回のよう な減肉管の圧罟厈力を表現できないことは明らかであ ๖.

\section{$4 \cdot 2$ 減肉管の圧壊圧力を示す式}

本実験で行ったような減肉管の圧壊王力を示す式を 実験結果に基らいて求的てみる。压壊压力る決定する 因子には，減肉部分の各寸法，すなわち肉厚 $t$ ，長さ $l$, 角度 $\theta$, の他に, 管経 $2 r_{0}$, 材質 $E, \nu$ 和上び材 料の強度 $\sigma_{y}$ が考学られるが, 同一材料, 寸法の管を 素材にしているため， $\gamma_{0} ， E ， \nu ， \sigma_{y}$ については考え ないことにする。

政小な隇肉部を考えたときこの部分に加わる外死 
を減肉部分の周囲のせん断応力によって受けると仮定 すると, 圧壊圧力は, $\theta$ に関して

$$
P_{\mathrm{c}} \propto A+1 / \theta
$$

なる形をもっと予測される.定数 $A$ は, $l$ 扰よび $t$ の 関数であるが簡単のために $t$ の一次形であると仮定す る. Table II に拀いて示したように $\theta=0^{\circ}$ でも圧壊 することを考光て，(3)式の $\theta$ の代りに $\theta+\theta_{0}$ と拉く と, (3)式は

$$
P_{c} \propto A t+1 /\left(\theta+\theta_{0}\right)
$$

と扰ける。

つぎに，l関しても同様の考方方に基づき，かつ (2)式からのアナロジーによって，

$$
P_{c} \propto B t+1 /\left(l+l_{0}\right)^{2}
$$

なる形を想定する。 また， $t$ 関しては単に $P_{c} \propto t^{\alpha}$ と考觉ると，(3)'式和よび(4)式より，圧壊压力 $P_{c}$ は $l$, $\theta, t$ の関数として

$$
P_{c}=P_{0} t^{\alpha}\left\{1 /\left(\theta+\theta_{0}\right)+A t\right\}\left\{1 /\left(l+l_{0}\right)^{2}+B t\right\}
$$

なる形が得られる。 $\theta_{0}$ および $l_{0}$ の值は, 減肉部の端 部で, 肉厚が $1.1 t$ となる部分まで減肉部として拡張 することにより

$$
\theta_{0}=5^{\circ}, l_{0}=6 \mathrm{~mm}
$$

が得られる、このことは, Fig. 2 に示すように, 圧壊 変形した管の測定からも妥当な值である.

つぎに(5)式の定数 $A$ 打よび $B$ を， $t, l$ あるいは $t$, $\theta$ を一定にしたデータよりそれぞれ独立に最小二乗法 によって求め, 最後に全データより $P_{0}$ と $\alpha$ を最小二 乗法によって求めた。励の結果,

$$
\begin{aligned}
P_{c}= & 3.89 \times 10^{4} \times t^{-0.221}\{1 /(\theta+5)+0.672 t\} \\
& \times\left\{1 /(l+6)^{2}+0.0157 t\right\}
\end{aligned}
$$

が得られたたただし， $t, l$ はm は $\mathrm{kg} / \mathrm{cm}^{2}$ で表している。な打前述のように(2)式から 予測できる $\alpha$ の值は 1 であり， Fig. $3 ４$ 上り予測さ れる值は一0. 5 であったが，最小二乗法で得られた值 はー0.221 であり，(6)式はかなり実験結果より予測さ れる值に近い。な拉 Fig. 3，4 亿示した実線抒よび Table II の最右欄の值は(6)式から計算した值を示し たものである.

\section{$4 \cdot 3$ 実験值と圧壞圧力を表す式との比較}

上で求めた圧壊圧力 $P_{c}$ と実験結果を比較したもの が Fig. 5〜8 である. Fig. 5 は $l=20 \mathrm{~mm}$ の結果を, 減肉角 $\theta$ を横軸にとって示したるので, 実験結果を点 で，(6)式で計算した值を実線にて示した．各実験点に 付した数字は隇肉部の肉厚 $t$ である. Fig. 6 は減肉角 $\theta=30^{\circ}$ に対して減肉部長さ $l$ を横軸にとって結果を 示したものである. Fig. 7, 8 は $l=10$ 抢よび $20 \mathrm{~mm}$ に対して, 実験值 $P_{e}$ を縱軸に, (6)式による計算値 $P_{c}$ を横軸にとって示したものである. 図中*印を付した 点は，Table II で*印を付したデータである。これ
らの点はいずれも実験值が計算值よりも小さくでてき ている.このことは，減肉部が近接して 2 か所にある ため変形抵抗が減少したためと考穴られる。このよう な干渉効果についてはさらに今後研究すべきことであ ると考えている.

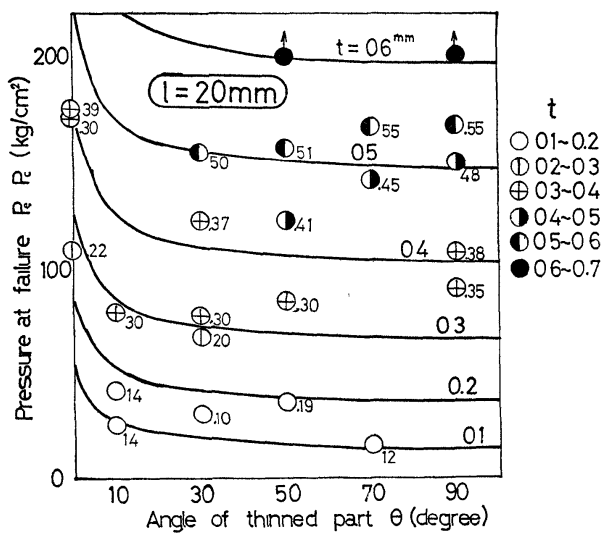

Fig. 5. Effect of angle of thinned part $\theta$ on results (Numbers beside point and lines indicate the thickness $t(\mathrm{~mm}))$.

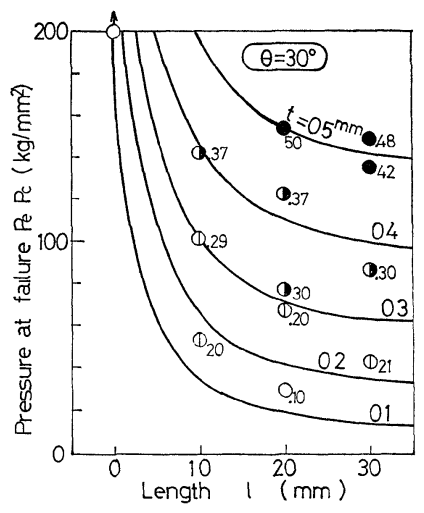

Fig. 6. Effect of length of thinned part $l$ on results.

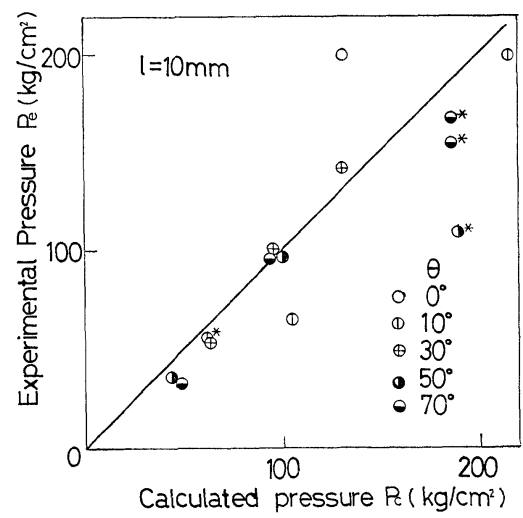

Fig. 7. Comparison of experimental results with calculated ones. $(l=10 \mathrm{~mm})$ 


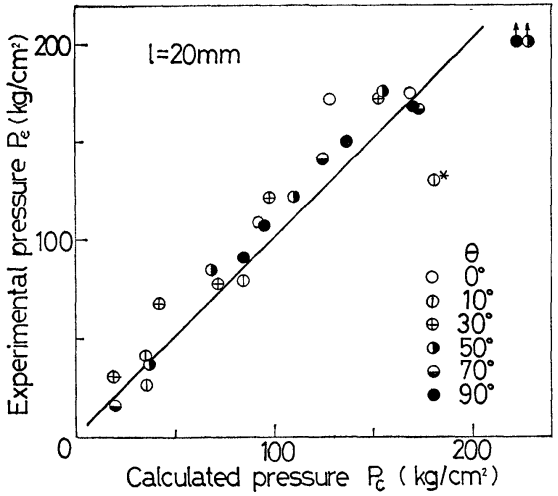

Fig. 8. Comparison of experimental result with calculated ones. $(l=20 \mathrm{~mm})$

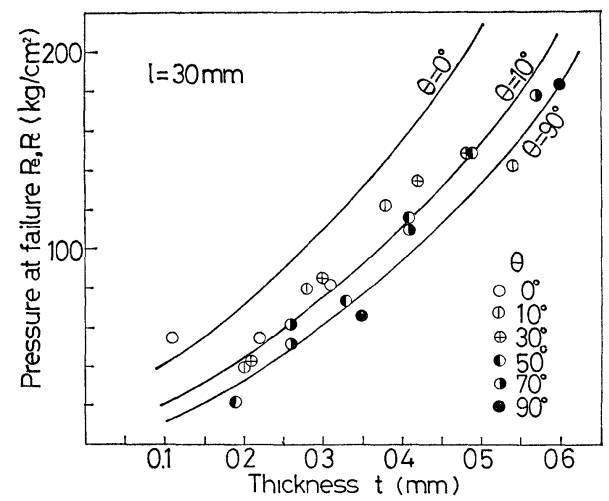

Fig. 9. Effect of thickness at thinned part $t$ on result.

Fig. 9 は $l=30 \mathrm{~mm}$ 飞対して横軸飞減肉部肉厚 $t$ を とり, 減肉角 $\theta$ をパラメータにとって実験結果と, 計 算值を比較したものである.

実験結果のばらつきを考慮すれば，Fig.5〜9でみ るように，(6)式はかなりよく実験結果を代表している といえる.

\section{$4 \cdot 4$ 三木の実験との比較}

伊方の原子力発電所建設に関する行政訴訟（いわゆ る伊方原発訴訟）に批いて，被告の国側が，減肉管の 内外压詨する強度を保障するものとして提出した三 木の実験結果と我々の結果を比較してみる。この実験 では, インコネル 600 のウェスチングハウス社タイプ の伝熱管に，Fig. 10 に示すような形状の減肉を与兄 たときの強度を実験的に求めている. 三木の実験の内, 外圧に対する圧壊強度の結果の久を Fig. 11 飞書き直 して示した。この実験では圧壊圧力がいずれも200 $\mathrm{kg} / \mathrm{cm}^{2}$ を越えて拈り, 原子力発電所の一次冷却水が LOCA 時なぞにたとえ $0 \mathrm{~kg} / \mathrm{cm}^{2}$ になっても，二次冷 却水の圧力 $75 \mathrm{~kg} / \mathrm{cm}^{2}$ の外圧以上であり, 減肉率 $\left(t^{\prime}\right.$ $-t) / t^{\prime}$ が $95 \%$ 以上 $(t=0.08 \mathrm{~mm})$ になっても圧壞し

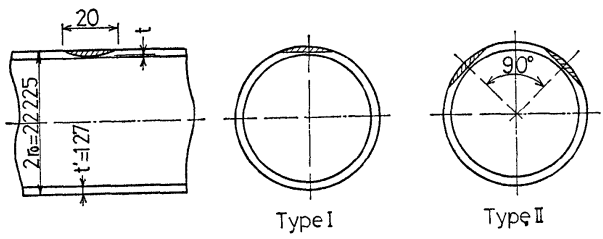

Fig. 10. Test specimen of Miki's experiment. (Shadowed parts were thinned out)

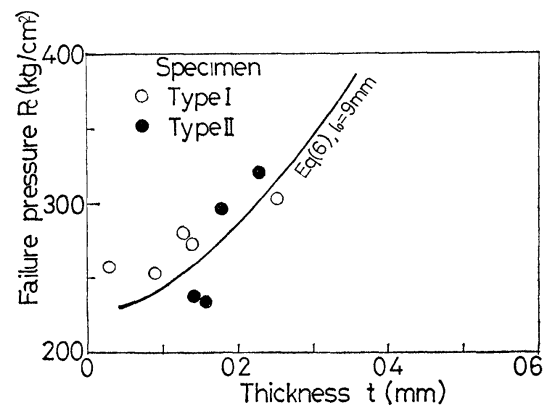

Fig. 11. Miki's experimental result5).

ないと述べている，しかし三木の実験は，著者達の実 験に护ける $l=0 \mathrm{~mm}, \theta=0^{\circ}$ に相当するものであり， 我々の実験管囲の極く一部分にしか過ざない。

Fig. 12 は我々の実験結果の内 $\theta=0^{\circ}$ に対する結果 を $l$ をパラメータにして示したすのである. $l=0 \mathrm{~mm}$ ， $\theta=0^{\circ}$ では明らかに圧壊圧力は $200 \mathrm{~kg} / \mathrm{cm}^{2}$ を越穴て いるが，lが $20 \mathrm{~mm}, 30 \mathrm{~mm}$ の実験値は，200 kg/ $\mathrm{cm}^{2}$ より低くなり, $l=30 \mathrm{~mm}$ で $t=0.22 \mathrm{~mm}$ の試験 片は $55 \mathrm{~kg} / \mathrm{cm}^{2}$ の外压で圧壊している.

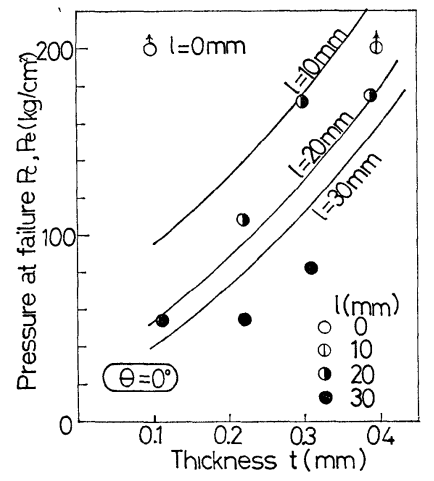

Fig. 12. Result at $\theta=0^{\circ}$.

通常減肉は $\theta=0^{\circ}, l=0 \mathrm{~mm}$ の形に限定できるもの ではなく，かなりのひろがりをるっているものであり， 三木の実験結果のように限定された条件から得られる 結論「減肉率が $95 \%$ でも圧壊圧力は $200 \mathrm{~kg} / \mathrm{cm}^{2}$ を越 えるから, 外圧 $75 \mathrm{~kg} / \mathrm{cm}^{2}$ の蒸気細管は安全である.」 といらことは間違っているといえよう.

な祀三木の結果は(6)式で計算される值よりも小さい 
が，これ㤨給管の肉厚 $t^{\prime}$ が異るためと, 減肉部の 曲率半径 $R$ が異るためで, 三木の試験片の方が変形し やすいためである. (5)式の $l_{0}$ の值に， $l_{0}=9 \mathrm{~mm}$ の值 を代入して計算した結果を Fig. 11 飞図示したが，三 木の実験結果をるよく表していることがわかる。なお， 三木の実験結果の内, 減肉率が $60 \%$ 以下の場合は全断 面の影響が現れてくるので比較の対象から除外した.

\section{5 結言}

減肉管の外圧による圧壊変形抵抗を求めるために, 呼び径20の供試管に, 減肉部の長さ, 肉厚, 減肉角度 をパラメータとした一連の実験を行った，その結果， 得られた結論は次のと拈りである。

（1）薄肉管の圧壊（座屈）圧力を示す弾性式は，減 肉管には適用できない。

（2）減肉管の圧壊圧力を示す式を導いたが，実験範 囲内で，実験結果と良い一致を示した，薄肉円管での 座屈圧力は，肉厚 $t$ の 3 乗に比例するが，減肉管では tの 1.78 乗に比例する式となった.
（3）減肉部があるひろがりをもてば，非常に低い外 圧によっても，減肉部は容易に圧壊変形し，開口する ので, 配管の安全管理には充分な配慮が払われるべき である.

（4）減肉部が近接して二つ以上存在する場合, 变形 抵抗の減少により，(6)式で与兄られる圧壞圧力より低 い圧力で圧壊する。

(昭和 52 年 5 月 25 日 日本材䉼学会第 26 期総会学術講寅会にて講寅)

\section{参 考 文 献}

1）安藤良夫, 岡林邦夫, “原子カプラントの構造設計（原 子力工学シリーズ， 3)”，126（1977）東大出版会

2) 河本 実, “材料力学”, 161 (1973) 共立出版

3) Timoshenko, S. P., and J. M. Gree, "Theory of Elastic Stability", 289 (1936) McGraw-Hill

4) Timoshenko, S. P., and J. M. Gree, "Theory of Elastic Stability" 498 (1936) McGraw-Hill

5）三木孝夫, “蒸気発生器伝熱管の強度試験結果”（1977） 三菱重工業高砂工場技術報告 